\title{
Philometrids (Nematoda: Philometridae) from fishes of Lake Turkana, Kenya, including two new species of Philometra and erection of Afrophilometra gen. $n$.
}

\author{
František Moravec $^{1}$, Harrison Charo-Karisa ${ }^{2}$ and Miloslav Jirků ${ }^{1}$ \\ ${ }^{1}$ Institute of Parasitology, Biology Centre of the Academy of Sciences of the Czech Republic, Branišovská 31, 37005 České \\ Budějovice, Czech Republic; \\ ${ }^{2}$ Kenya Marine and Fisheries Research Institute, Sangoro Research Centre, P.O. Box 136, Pap-Onditi, Kenya
}

\begin{abstract}
The following four species (only females available) of the Philometridae (Nematoda: Dracunculoidea) were recorded from freshwater fishes of Lake Turkana, northwestern Kenya in 2007-2008: Philometra bagri (Khalil, 1965) from the subcutaneous tissue around the mouth, on gill covers and the fin base of the bayad Bagrus bajad (Forsskål) (Bagridae: Siluriformes), Philometra lati sp. n. from the abdominal cavity of the Nile perch Lates niloticus (Linnaeus) (Latidae: Perciformes), Philometra spiriformis sp. n. from capsules on the inner surface of gill covers of L. niloticus and Afrophilometra hydrocyoni (Fahmy, Mandour et El-Nafar, 1976) comb. n. from the fins of Hydrocynus forskahlii (Cuvier) (Alestidae: Characiformes). The new species P. lati is characterized mainly by the presence of distinct oesophageal teeth, absence of large cephalic lobes and caudal projections, and by a combination of other features. Philometra spiriformis differs from all congeners principally in the spirally coiled body and from individual species by a combination of other morphological features. The already known species P. bagri and A. hydrocyoni are redescribed based on light and scanning electron microscopy; findings of both these species in Kenya represent new geographical records.
\end{abstract}

Key words: Philometra, Afrophilometra, parasitic nematode, freshwater fish, Lates, Hydrocynus, Lake Turkana, Kenya, Africa

The fauna of philometrid nematodes parasitizing freshwater fishes in Africa is little known. To date, only four nominal species, all described solely from females, have been reported: Nilonema gymnarchi Khalil, 1960 from the swimbladder of Gymnarchus niloticus Cuvier (Gymnarchidae) in the Sudan, Philometra bagri (Khalil, 1965) from the subcutaneous tissue of Bagrus bajad (Forsskål) (Bagridae) in the Sudan and Egypt, Philometroides hydrocyoni Fahmy, Mansour et El-Nafar, 1976 from the fins of Hydrocynus forskahlii (Cuvier) and $H$. vittatus Castelnau (syn. H. lineatus) in Egypt, and Philometroides africanus Moravec et Van As, 2001 from gill arches and operculum of Hepsetus odoe (Bloch) (Hepsetidae) in South Africa (Khalil 1960, 1965, 1969, 1974, Fahmy et al. 1976, El-Nafar et al. 1983, Moravec and Van As 2001). Two unidentified species of Philometroides Yamaguti, 1935 were recorded from Labeo altivelis Peters (Cyprinidae) in Zimbabwe (Khalil 1974) and from Lates niloticus (Linnaeus) (Latidae) in Egypt (El-Nafar et al. 1983). Boomker (1994) reported unidentified species of the Philometridae from Schilbe intermedius Rüppel (Schilbeidae), Serranochromis meridianus Jubb (Cichlidae) and Synodontis zambezensis Peters (Mochokidae) in South Africa (see also Khalil and Polling 1997). Philometra congolensis
Schuurmans Stekhoven, 1937 described from Clarias sp. in the then Belgian Congo (= Democratic Republic of Congo, former Zaire) proved to be a misidentification of Eustrongylides larvae (Moravec 2006). To date, no philometrid nematodes have been reported from Kenya.

During recent studies of fish parasites of Lake Turkana, northwestern Kenya carried out by M. Jirků in 2007 and 2008, four species of nematodes belonging to the Philometridae were recovered from Bagrus bajad, Hydrocynus forskahlii and Lates niloticus. A subsequent examination showed that they represent two already known and two new, previously undescribed species. The study of their morphology, including scanning electron microscopy, made it possible to describe two new species and redescribe the two others.

The Nile perch, Lates niloticus, is a freshwater tropical, carnivorous, highly commercial fish, utilized also as a gamefish and for aquaculture. It may attain a body length of $200 \mathrm{~cm}$ and the maximum weight $200 \mathrm{~kg}$. Hydrocynus forskahlii is a freshwater tropical, carnivorous, commercial fish serving also as a gamefish, with the maximum body length $78 \mathrm{~cm}$ and the maximum weight up to 15.5 $\mathrm{kg}$. The bagre, Bagrus bajad, is a freshwater tropical commercial fish and gamefish, attaining maximum body 
length $112 \mathrm{~cm}$ and weight $12.5 \mathrm{~kg}$. These three species are widespread throughout northern and central sub-Saharan Africa in major basins including the Nile, Chad, Niger, Senegal, Sanaga, Volta, Gambia, Congo, small basins of the Upper Guinea, and in the isolated basin of the Turkana Lake - Omo River system (FishBase - Froese and Pauly 2008).

\section{MATERIALS AND METHODS}

Fishes were caught using gill nets and seine nets (Lates, Bagrus) or by trolling (Hydrocynus) by local fishermen at three localities in Lake Turkana, northwestern Kenya. Locality 1: Todonyang village $\left(4^{\circ} 27^{\prime} 10^{\prime} \mathrm{N}, 35^{\circ} 56^{\prime} 30^{\prime \prime} \mathrm{E}\right)$. The collecting locality is a bay adjacent to the village in western part of the Omo River delta at the very north end of the lake. Freshwater part of Lake Turkana (pH 6.82, conductivity 14.9). Limnic habitats characterized by shallow cloudy waters with maximum depth $1.5 \mathrm{~m}$ and extensive areas of littoral reedy vegetation. Local fishermen use gill nets set among reeds. Locality 2: Kalokol, a former fishing lodge at the northern end of Longech spit (peninsula) forming the eastern bank of Ferguson's Gulf (3 $\left.3^{\circ} 33^{\prime} 17^{\prime \prime N}, 35^{\circ} 54^{\prime} 56^{\prime \prime E}\right)$ at the central part of the lake. Semi-saline, highly alkaline $(\mathrm{pH}$ 8.02 , conductivity 356) part of the lake. Lakeshore habitats are characterized by shallow waters with a gently sloping sandy bottom devoid of vegetation. Local fishermen use seine nets operated from the shore. Locality 3: El-Molo Bay $\left(2^{\circ} 50^{\prime} 00^{\prime} \mathrm{N}\right.$, $\left.36^{\circ} 41^{\prime} 50^{\prime \prime} \mathrm{E}\right)$. Semi-saline, highly alkaline ( $\mathrm{pH} 8.98$, conductivity 378 ) part of the lake, characterized by shallow waters with gently sloping sandy/gravel bottom devoid of vegetation. Local fishermen use both gill and seine nets. Just recently, fishing rod use is being introduced.

Immediately after collection, all fishes were placed in 70 100-1 tanks filled with aerated lake water, transported alive to the field base and kept for a maximum of $5 \mathrm{~h}$ before dissection. Upon dissection, each fish was measured and weighed and liver tissue sample removed and preserved in absolute ethanol for DNA isolation. The nematodes were dissected out from freshly killed fish and, after washing in physiological saline, they were fixed in hot $4 \%$ formaldehyde solution in saline. Wherever possible, selected nematode specimens were preserved in absolute ethanol for DNA isolation. For light microscopy (LM), the nematodes were cleared with glycerine. Drawings were made with the aid of a Zeiss drawing attachment. Specimens used for scanning electron microscopy (SEM) were postfixed in $1 \%$ osmium tetroxide (in phosphate buffer), dehydrated through a graded acetone series, critical point dried and sputter-coated with gold or platina; they were examined using a JEOL JSM-7401F scanning electron microscope at an accelerating voltage of 3 or $4 \mathrm{kV} \mathrm{GB}$ low. All measurements are in micrometres unless otherwise indicated. The names of fishes follow FishBase (Froese and Pauly 2009).

\section{DESCRIPTIONS}

Philometra bagri (Khalil, 1965) Moravec et Nagasawa, 1989

Figs. 1, 2, 9A

Syn.: Thwaitia bagri Khalil, 1965.

Female (6 gravid specimens; measurements of smallest subgravid specimen in parentheses): Body of fixed specimens yellowish (live specimens red-coloured), 19.61-25.98 (8.88) mm long, maximum width 490-653, somewhat tapering at both ends. Width of cephalic end 136-150 (109), of posterior end 109-122 (106). Maximum width/length ratio of body 1:30-42 (1:31). Cuticle smooth. Cephalic end blunt, with four large, strongly elevating rounded submedian fleshy projections 6-9 (12) high, regularly arranged around mouth; each projection with two indistinct cephalic papillae of external circle. Oral aperture oval, surrounded by six small simple papillae (two lateral and four submedian) of internal circle; lateral amphids slightly outlined. Bottom of mouth formed by surfaces of three oesophageal sectors. Oesophagus muscular, long, its anterior end forming well-developed bulb 63-90 (60) long and 75-84 (66) wide. Greater posterior portion of oesophagus with well-developed dorsal oesophageal gland provided with large cell nucleus at middle situated 0.98-1.20 (0.86) $\mathrm{mm}$ from anterior extremity; gland opening anteriorly short distance posterior to level of nerve ring and extending posteriorly to small ventriculus. Entire oesophagus including anterior bulb 1.69$1.88(1.36) \mathrm{mm}$ long, representing $7-10 \%$ (15\%) of body length; maximum width at its part including oesophageal gland 122-177 (82). Small ventriculus 33-45 (15) long and 33-51 (39) wide. Oesophagus opening into intestine through distinct valve. Nerve ring 190-218 (190) from anterior extremity. Intestine brownish, narrow including its anterior part, ending blindly; its posterior end attached by long ligament to body-wall near posterior extremity; length of ligament $0.68-1.77$ (1.06) $\mathrm{mm}$. Posterior end of body with two large, lateral, cone-shaped caudal projections 41-68 (41) long. Ovaries narrow, long, reflected, situated near body ends. Uterus occupying almost entire space of body. Uterus contains large number of larvae and some eggs. Larvae 381-411 long $(\mathrm{n}=5)$ and $16-18$ wide, with rounded anterior and sharply pointed posterior ends; length of oesophagus $108-120$ (28-31\% of body length), of tail $75-81$ (19-20\% of body length).

Male: Unknown. 
A

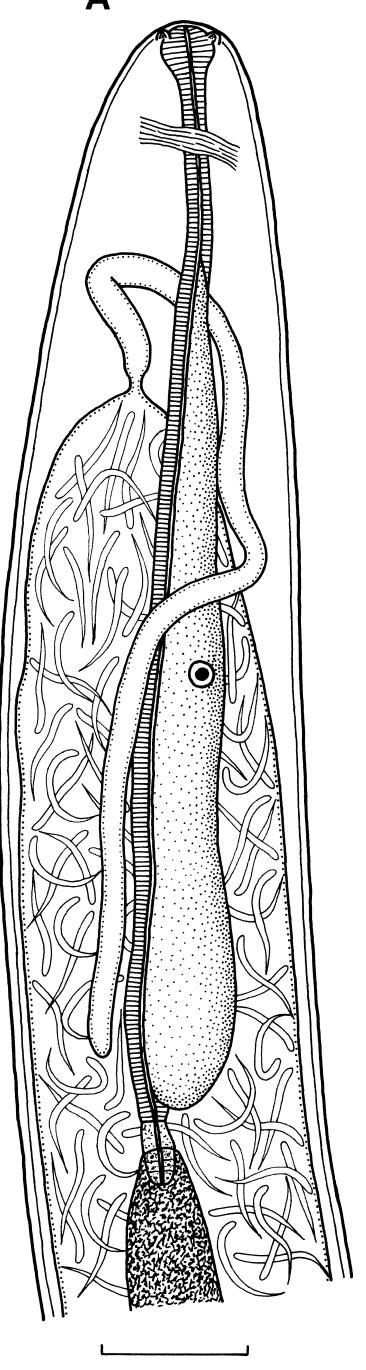

B
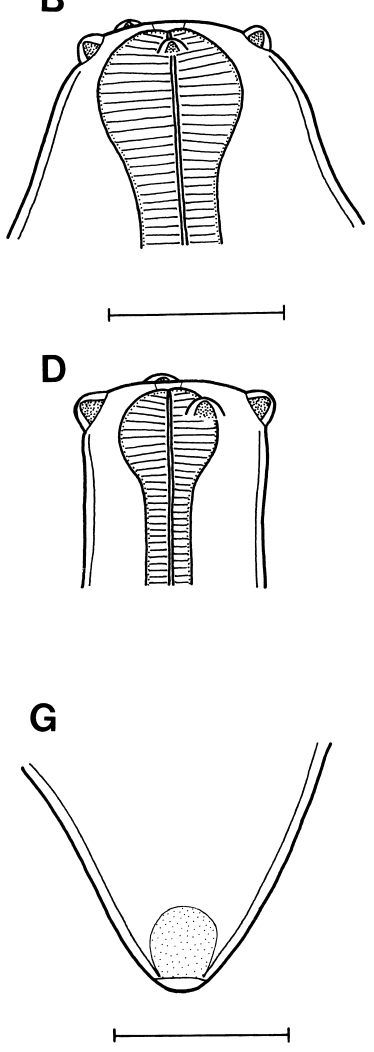

$\mathbf{H}$

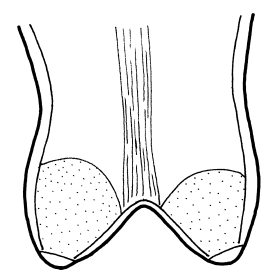

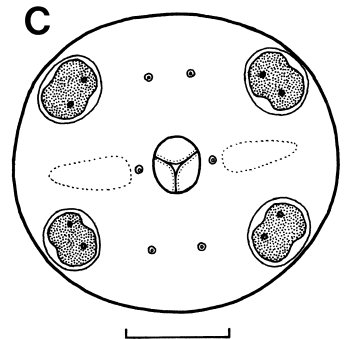

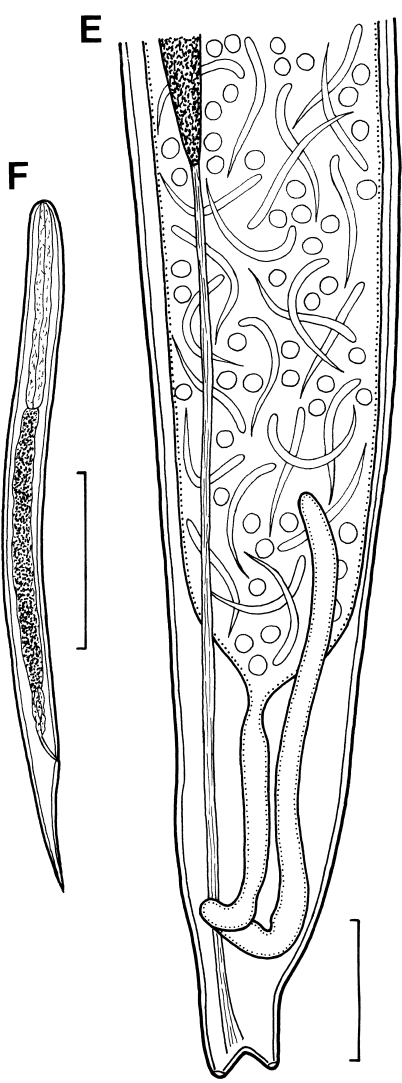

Fig. 1. Philometra bagri (Khalil, 1965), female. A - anterior end of gravid specimen; B, C - cephalic end of gravid specimen, lateral and apical views; D - cephalic end of smallest subgravid specimen, lateral view; $\mathbf{E}$ - posterior end of gravid specimen, dorsoventral view; $\mathbf{F}$ - larva from uterus, lateral view; $\mathbf{G}, \mathbf{H}$ - caudal end of gravid specimen, lateral and dorsoventral views. Scale bars: A, $\mathrm{E}=200 \mu \mathrm{m} ; \mathrm{B}, \mathrm{D}, \mathrm{F}-\mathrm{H}=100 \mu \mathrm{m} ; \mathrm{C}=20 \mu \mathrm{m}$.

H o s t: Bayad, Bagrus bajad (Bagridae, Siluriformes).

Sites of infection: Under skin, mostly around mouth and on outer surface of gill covers, with sole specimen on the base of pectoral fin.

L oc a lity: Todonyang, Lake Turkana, Kenya. Collected 10 September 2008.

Prevalence and intensity: Todonyang: of 11 specimens examined, 2 (18\%) infected. One parasitized fish (standard length: $330 \mathrm{~mm}$, weight: $370 \mathrm{~g}$ ) harboured $21 \mathrm{nem}-$ atodes and another one (standard length: $365 \mathrm{~mm}$, weight: $500 \mathrm{~g}) 1$ nematode. No infection recorded in 5 specimens of B. bajad from Kalokol.

Deposition of voucher specimens: Helminthological Collection of the Institute of Parasitology, Biology Centre of the Academy of Sciences of the Czech Republic, České Budějovice (Cat. No. N-919).
Comments: The morphology and measurements of the present specimens are, more or less, in agreement with the original description of Philometra (reported as Thwaitia) bagri based on LM, provided by Khalil (1965). The author observed only the four cephalic protrusions (reported as "four fleshy papillae") and a pair of minute amphids on the female cephalic end. However, the SEM study, used for the first time in this species, has also revealed the presence of six small papillae of the internal circle, which are typical of many other Philometra spp. (Moravec 2006). The structure of the four cephalic protrusions of $P$. bag$r i$ is similar to that in P. rischta Skryabin, 1923, a parasite of subcutaneous tissues of Palaearctic cyprinids, as described by Moravec (1994), i.e., each fleshy protrusion bearing a pair of minute, poorly visible papillae of the 


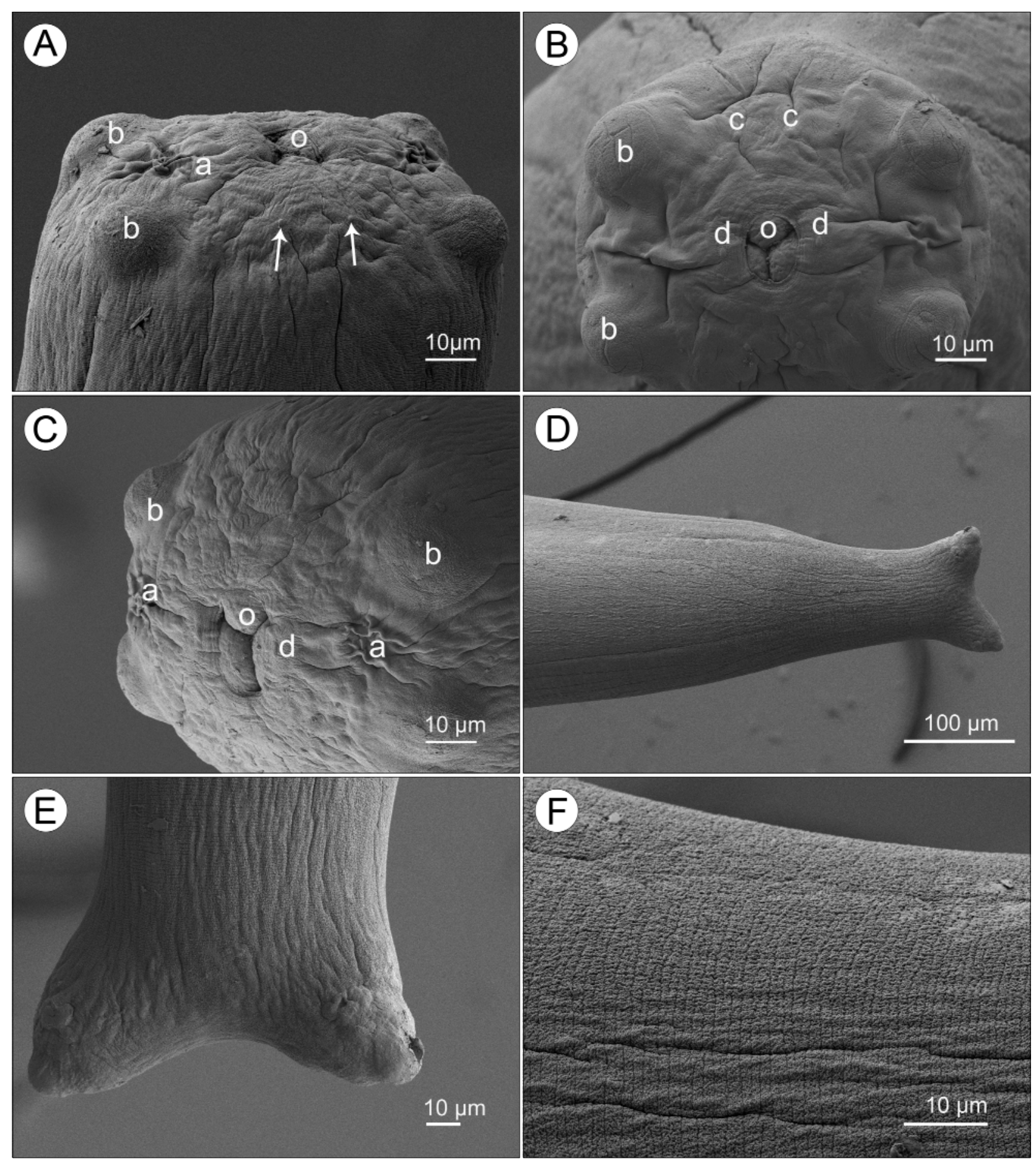

Fig. 2. Philometra bagri (Khalil, 1965), scanning electron micrographs of gravid female. A - cephalic end, dorsoventral view (arrows indicate submedian papillae of internal circle); $\mathbf{B}$ - cephalic end, apical view; $\mathbf{C}$ - cephalic end, subapical view; $\mathbf{D}$ - posterior part of body, ventral view; $\mathbf{E}$ - caudal end, ventral view; $\mathbf{F}$ - detail of body surface. Abbreviations: $a$ - amphid; $b$ - cephalic protrusion; $\mathrm{c}$ - submedian papilla of internal circle; $\mathrm{d}$ - lateral papilla of internal circle; $\mathrm{o}$ - oral aperture.

external circle. Sokolov and Kazakov (2007) in their recent redescription of $P$. rischta reported only one laterally situated papilla on each protrusion, but SEM examination of the same species carried out by Moravec (unpublished) did not confirm this. Khalil (1965) reported that in $P$. bagri the "mouth opening is guarded by three raised flaps, forming a prominent triangular cone", but no such structures were revealed by SEM in the present study.

Philometra bagri was first described by Khalil (1965) based on females collected from the subcutaneous tissue 
of the head of Bagrus bajad in the Nile River near Khartoum, Sudan (see also Khalil 1969). Later this nematode was also recorded from the same host species of the Nile River in Assiut, Egypt (Fahmy et al. 1976, El-Nafar et al. 1983). The present finding of $P$. bagri in Lake Turkana is the first record of this parasite outside the Nile River and Kenya represents its new geographical record.

According to Khalil (1965), the gravid females of $P$. bagri occurred in about $30 \%$ of $B$. bajad in the Sudan, and only from December to the end of February or early March. Fahmy et al. (1976) recorded this parasite in only $2 \%$ of B. bajad examined in Egypt. The present finding of $P$. bagri in Kenya indicates its common occurrence in B. bajad of Lake Turkana, where, in contrast to the Sudan, both gravid and subgravid females were found as early as September; it also shows that in addition to the subcutaneous tissue of the host's head (just laterally to the mouth), as reported by Khalil (1965), the females of $P$. bagri may be also located on the fish gill covers and at the base of fins. A similar location of gravid females in the subcutaneous tissue of the head and also in the gill covers and fins is known for some other philometrid species, for example Philometra rischta or Philometroides paralichthydis Moravec et de Buron, 2006 (see Moravec 2006, Moravec and de Buron 2006).

\section{Philometra lati sp. $\mathrm{n}$.}

Figs. 3, 4

Female (3 gravid specimens; measurements of holotype in parentheses): Body of fixed specimens grey-coloured (live specimens red-coloured), transparent, filiform, somewhat tapering at both ends; posterior end distinctly narrower than anterior end. In all observed live specimens, body somewhat curled, obviously unable to stretch out completely. Body 71-201 (185) mm long, its maximum width at middle 544-1,061 $(1,061)$; maximum width/body length ratio 1:131-221 (1:174). Cuticle smooth. Cephalic end rounded, 177-245 (245) wide, with distinctly protruding oesophageal teeth; cephalic papillae very small, indistinct when viewed laterally. Oral aperture large, oval, surrounded by 14 small cephalic papillae arranged in two circles and slightly outlined lateral amphids; internal circle of papillae consisting of four submedian and two lateral single papillae, whereas external circle formed by four submedian pairs of papillae. Oesophagus including anterior bulbous inflation 1.67-2.37 (1.67) mm long, representing 1-3\% (1\%) of body length; bulb 136-177 (177) long and 150-190 (190) wide; oesophagus distinctly narrowed at region of nerve ring. Oesophageal gland marked, extending anteriorly from posterior end of oesophagus to short distance posterior to nerve ring; large oesophageal gland nucleus 1.66-2.24 (1.85) mm from anterior extremity. Nerve ring 422-530 (530) from anterior end of body. Small ventriculus 36-45 (36) long and 27-72 (60) wide. Oesophagus opening into intestine through distinct valve. Intestine dark, narrow, ending blindly, its posterior end attached to body wall near caudal end by liga- ment 150-218 (177) long. Vulva and anus absent. Ovaries long, narrow, reflected, situated near body ends. Uterus occupying most space of body, filled with numerous larvae and eggs; anteriorly uterus not reaching level of nerve ring. Larvae $(\mathrm{n}=5)$ from uterus 408-465 long, maximum width 24-26, length of oesophagus 132-165 (31-35\% of body length), of sharply pointed tail 75-87 (18-20\%). Caudal end rounded, 204-299 (204) wide; no caudal projections visible in two larger specimens, whereas one larger and one smaller papilla-like projections present (observed in lateral view) in smallest specimen.

Male: Unknown.

Type host: Nile perch, Lates niloticus (Latidae, Perciformes).

Site of infection: Abdominal cavity (outer surface of intestine).

Type locality: Todonyang, Lake Turkana, Kenya. Collected 9 September 2008.

O the r loc a lity: Kalokol, Turkana Lake, Kenya. Collected 28 August 2008.

Prevalence and intensity: Todonyang (type locality): of 3 Nile perch examined, 1 specimen (SL: $165 \mathrm{~mm}$, weight: $80 \mathrm{~g}$ ) infected with 2 nematodes. Kalokol: of 11 Nile perch examined, 1 (9\%) specimen (SL: $240 \mathrm{~mm}, 164 \mathrm{~g}$ ) infected with single $P$. lati.

Etymology: The specific name of this nematode relates to the generic name of the fish host.

Deposition of types: Holotype and paratype in the Helminthological Collection of the Institute of Parasitology, Biology Centre of the Academy of Sciences of the Czech Republic, České Budějovice (Cat. No. N-918).

Comments: Philometra lati is the first species of Philometra whose gravid females are parasitic in the abdominal cavity of a freshwater fish in Africa. It differs distinctly from the only two other congeners from African freshwater fishes: from $P$. bagri mainly in the absence of four cephalic lobes and large conical caudal projections, and from $P$. spiriformis sp. $\mathrm{n}$. in the shape and size of the body (straight vs. spirally coiled), a markedly more posterior location of the nerve ring, and in the presence of oesophageal teeth. Whereas both $P$. bagri and P. spiriformis are parasitic in the host's subcutaneous tissues, $P$. lati is a parasite of the abdominal cavity. To date, 30 species of Philometra are known with this location in the host (Moravec 2006, Moravec and Justine 2008, Moravec et al. 2008c); from all of them, P. lati can be easily distinguished by possessing distinct oesophageal teeth and from individual species also by a combination of other features.

Philometra lati is described from the same host species as $P$. spiriformis. A situation when two species of Philometra parasitize the same fish species is not exceptional and has been observed in some other freshwater, brackish-water, and marine fishes: Philometra cyprinirutili (Creplin, 1825) and P. rischta in Abramis spp. and $R u-$ tilus rutilus in Europe; Philometra margolisi Moravec, 
A
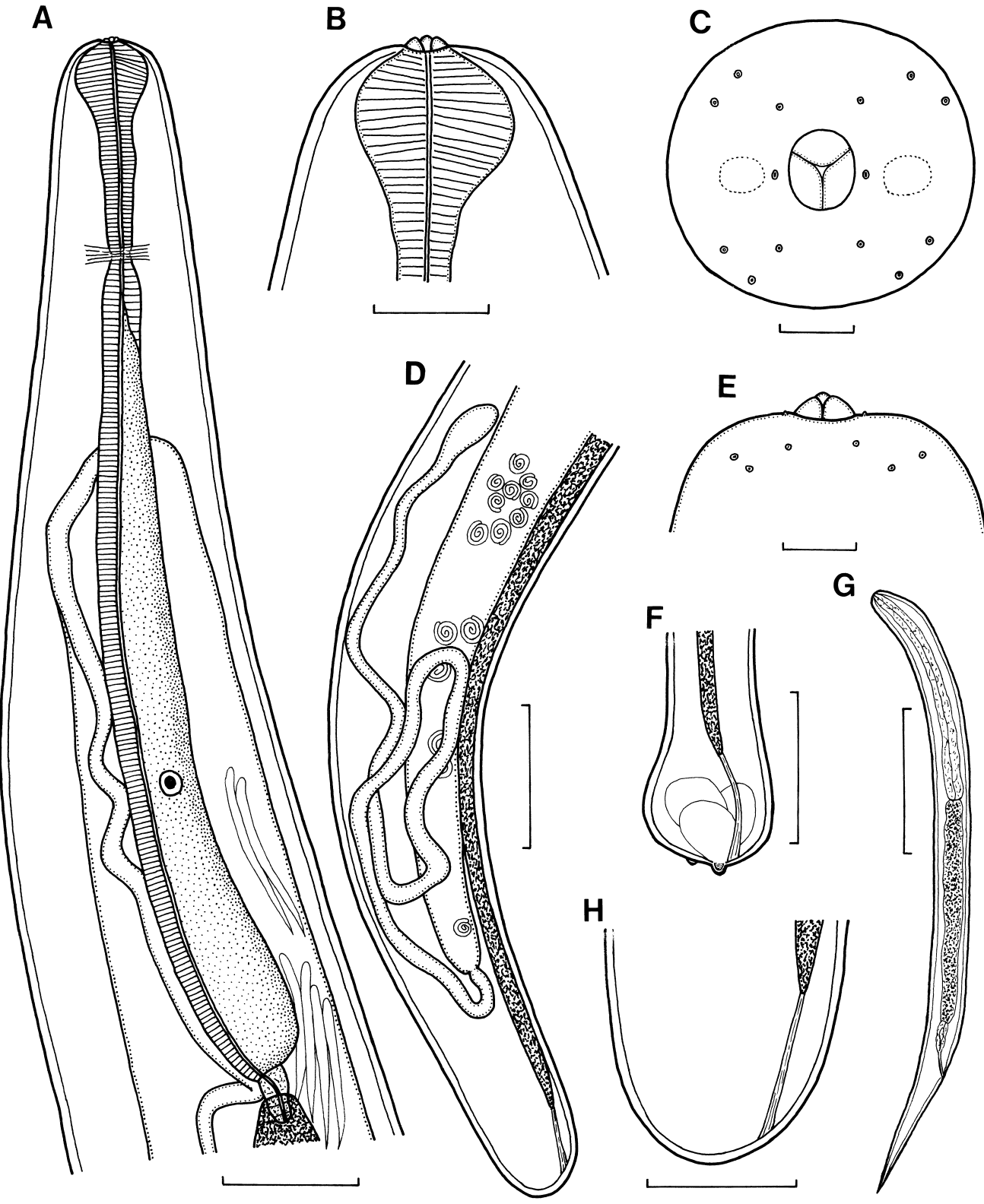

Fig. 3. Philometra lati sp. n., gravid female. $\mathbf{A}$ - anterior end, lateral view; $\mathbf{B}, \mathbf{C}$ - cephalic end, lateral and apical views; $\mathbf{D}$ - posterior end, lateral view; $\mathbf{E}$ - cephalic end, lateral view; $\mathbf{F}$ - caudal end of smallest specimen, lateral view; $\mathbf{G}$ - larva from uterus, lateral view; $\mathbf{H}$ - caudal end of female, lateral view. Scale bars: $\mathrm{A}=300 \mu \mathrm{m} ; \mathrm{B}, \mathrm{G}=100 \mu \mathrm{m} ; \mathrm{C}, \mathrm{E}=30 \mu \mathrm{m} ; \mathrm{F}, \mathrm{H}=200 \mu \mathrm{m} ; \mathrm{D}=500 \mu \mathrm{m}$.

Vidal-Martínez et Aguirre-Macedo, 1995 and P. salgadoi Vidal-Martínez, Aguirre-Macedo et Moravec, 1995 in Epinephelus morio in the Gulf of Mexico; Philometra managatuwo Yamaguti, 1941 and $P$. ocularis Moravec, Ogawa, Suzuki, Miyazaki et Donai, 2002 in Epinephelus septemfasciatus in the North Pacific; and Philometra carolinensis Moravec, de Buron et Roumillat, 2006 and P. cynoscionis Moravec, de Buron et Roumillat, 2006 in Cynoscion nebulosus (see Moravec 2006). In all these cases, the congeneric philometrids have always different sites of infection in the shared fish host.

\section{Philometra spiriformis $\mathrm{sp} . \mathrm{n}$.}

Figs. 5, 6, 9B,C

Gravid female (2 complete and 1 incomplete specimens; measurements of holotype in parentheses): Body of fixed specimens yellowish to grey (live specimens redcoloured), filiform, coiled into 12 (12) spirals. Body cylindrical, 39.95-47.08 (47.08) mm long, somewhat tapering at both ends; anterior end markedly narrowed at region anterior to nerve ring, posterior end broadly rounded; maximum width of body $843-1,591(1,591)$; width of cephalic end 150-163 (150), of caudal end 272-816 (340). Maximum body width/length ratio 1:26-30 (1:30). Cuticle almost smooth, with very fine transverse striation. Ce- 


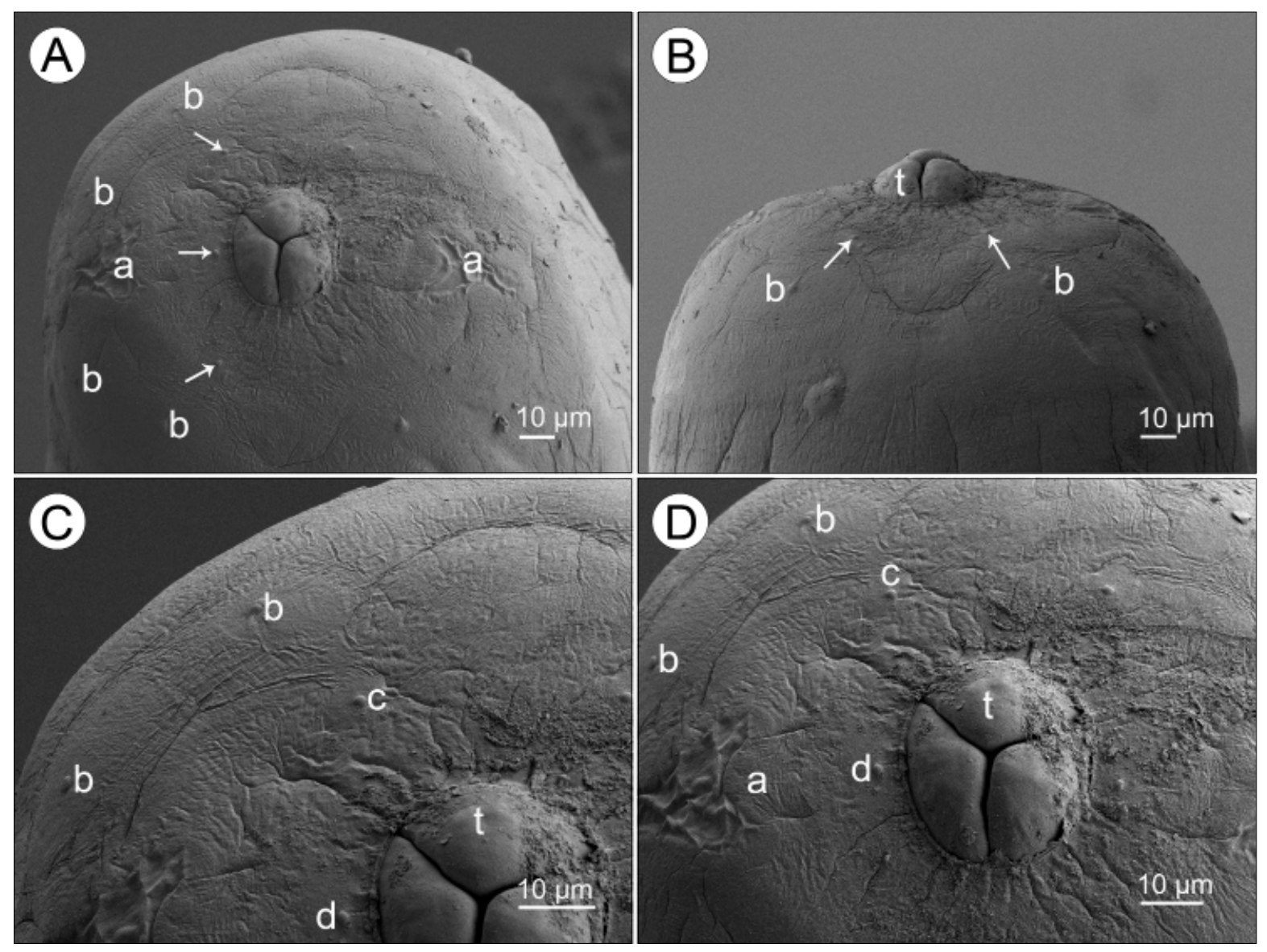

Fig. 4. Philometra lati sp. n., scanning electron micrographs of cephalic end of gravid female. A - apical view (arrows indicate papillae of internal circle); B - ventral view (arrows indicate submedian papillae of internal circle); $\mathbf{C}$ - enlarged part of cephalic end, apical view; D - region of oral aperture, apical view. Abbreviations: a - amphid; b - submedian papilla of external circle; $\mathrm{c}$ - submedian papilla of internal circle; $\mathrm{d}$ - lateral papilla of internal circle; $\mathrm{t}$ - oesophageal tooth.

phalic end blunt, provided with 14 small cephalic papillae and pair of indistinct amphids. Oral aperture large, oval, surrounded by four submedian pairs of small, rounded papillae arranged in external circle and six (2 lateral and 4 submedian) rounded single papillae of internal circle; submedian papillae of internal circle at level of subdorsal and subventral papillae of external circle. Bottom of mouth formed by flat surfaces of three oesophageal sectors. Anterior end of oesophagus swollen to form well-developed bulb 68-95 (82) long, and 82-95 (95) wide. Long posterior portion of oesophagus almost cylindrical, provided with well-developed, wide oesophageal gland extending anteriorly just posterior to level of nerve ring; oesophageal gland containing large cell nucleus located somewhat posterior to its middle. Overall oesophagus including anterior bulb 1.39-1.80 (1.36) mm, representing 3-7 (3)\% of body length; maximum width of cylindrical part including oesophageal gland 136-163 (163). Small ventriculus, 27 long and 105 wide in holotype, opening into intestine through valve. Nerve ring 150-159 (159) from anterior end of body. Intestine brownish, relatively narrow, its posterior end atrophied, forming short trans- lucent ligament 231-238 (231) long, attached ventrally to body wall near posterior extremity. Posterior end of body rounded, with two minute, hardly visible subterminal papilla-like caudal projections. Ovaries long, narrow, reflected. Uterus occupying major part of body, extending anteriorly nearly to level of nerve ring, posteriorly to anterior end of intestinal ligament. Uterus filled with numerous larvae (465-486) long and (18) wide $(\mathrm{n}=5)$; length of their oesophagus and sharply pointed tail (162-177) (35-36\% of body length) and (90-126) (19-26\% of body length), respectively.

Male: Unknown.

Type host: Nile perch, Lates niloticus (Latidae, Perciformes).

Site of infection: In transparent capsules on inner surface of gill covers.

Type locality: El-Molo Bay, Lake Turkana, Kenya. Collected September 2007.

O the r lo c a lity: Kalokol, Lake Turkana, Kenya. Collected 31 August 2008.

Prevalence and intensity: El-Molo Bay (type locality): a single Nile perch (SL: $340 \mathrm{~mm}$ ) harbouring 3 nema- 
A

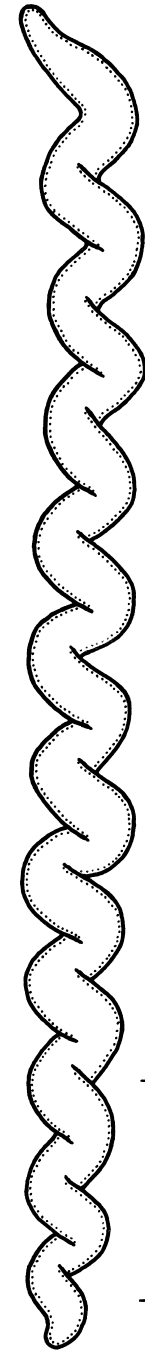

B
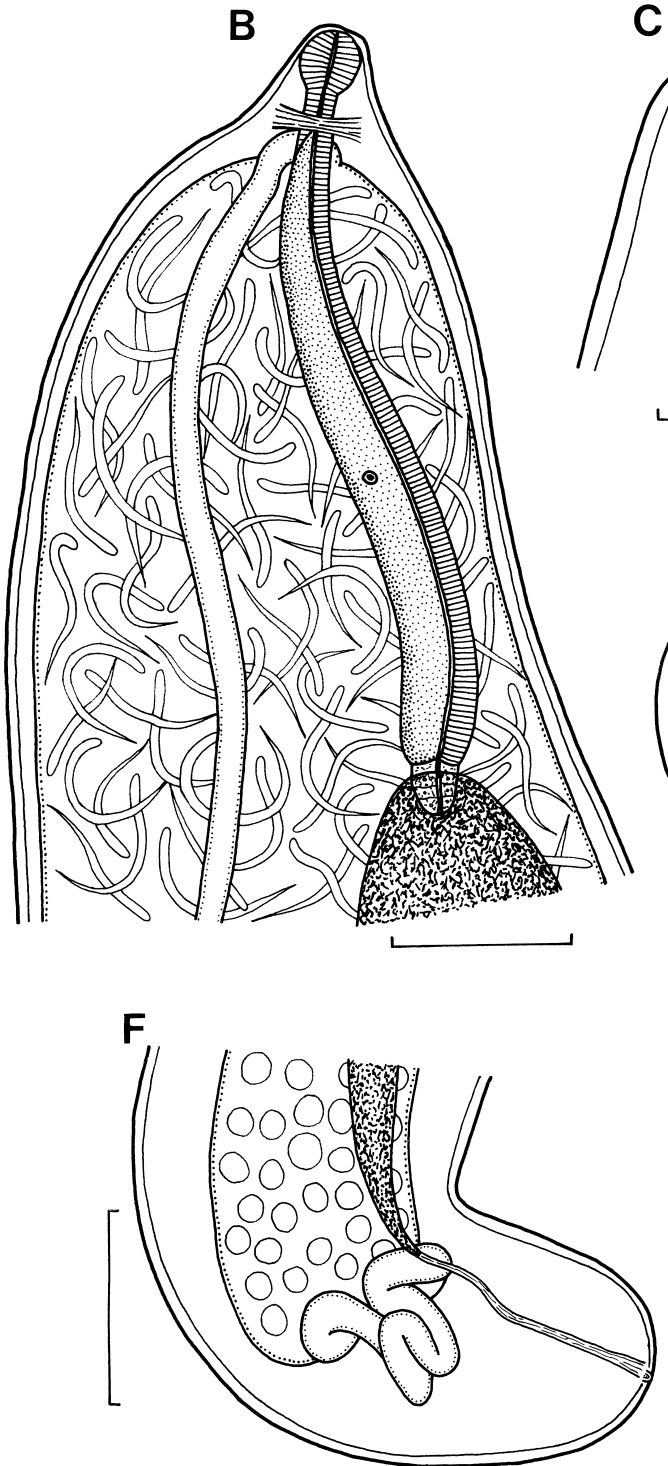

C
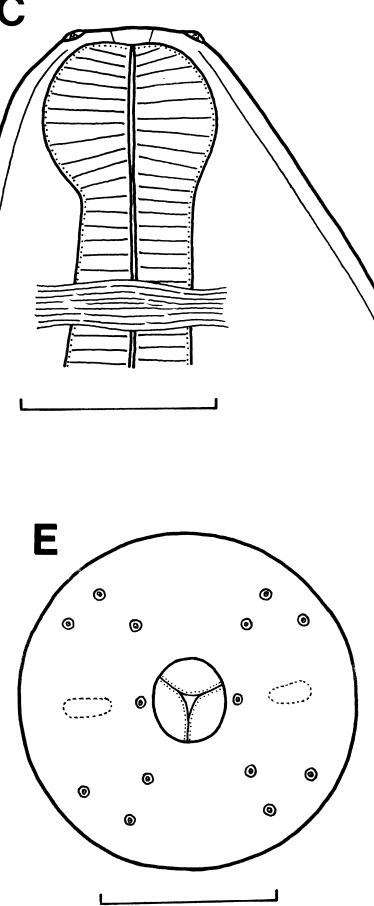

G

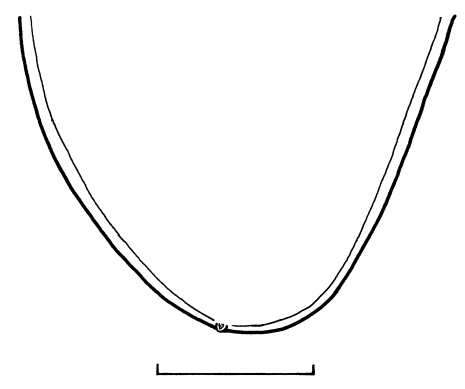

Fig. 5. Philometra spiriformis sp. n., gravid female. $\mathbf{A}$ - body shape of fixed specimen; $\mathbf{B}$ - anterior end of body; $\mathbf{C}$ - cephalic end, lateral view; D - larva from uterus; $\mathbf{E}$ - cephalic end, apical view; $\mathbf{F}$ - posterior end of body, lateral view; $\mathbf{G}$ - caudal end, lateral view (another specimen). Scale bars: $A=5 \mathrm{~mm} ; \mathrm{B}=300 \mu \mathrm{m} ; \mathrm{C}, \mathrm{D}=100 \mu \mathrm{m} ; \mathrm{E}=50 \mu \mathrm{m} ; \mathrm{F}, \mathrm{G}=200 \mu \mathrm{m}$.

tode specimens in one capsule was examined in 2007. All 3 Nile perches examined at the type locality in 2008 were free of infection. Kalokol: one (9\%) Nile perch (SL: $30 \mathrm{~mm}$, weight: $421 \mathrm{~g}$ ) of 11 examined harboured $2 P$. spiriformis in one capsule.

Etymology: The specific name of this nematode relates to the characteristic form of its gravid females; spiriformis (= spiral-shaped) is derived from Latin spira (= spiral) and forma (= shape, appearance).

Deposition of types: Holotype and paratypes in the Helminthological Collection of the Institute of Parasitology, Biology Centre of the Academy of Sciences of the Czech Republic, České Budějovice (Cat. No. N-915).

Comments: Philometrids exhibit a relatively high degree of host specificity (Rasheed 1963, Ivashkin et al.
1971, Moravec 2006) and individual species are characterized by their location in the host, particularly that of gravid females (Moravec 2004, Moravec and Ali 2005, Moravec et al. 2006). Moravec (2006) listed 71 species of Philometra Costa, 1845 considered to be valid, but an additional 13 congeneric species have been described since (Moravec et al. 2007a, 2008a,b,c, Moravec and SalgadoMaldonado 2007, Moravec and Justine 2008, Quiazon et al. 2008a,b, Caspeta-Mandujano et al. 2009). Moreover, Philometra jordanoi (López-Neyra, 1951) was revalidated by Moravec (2008), whereas P. centropomi Caballero, 1974 was transferred to the genus Spirophilometra Parukhin, 1971 by Moravec et al. (2007b). Accordingly, at present this genus includes a total of 84 species. Of them, only the following 16 have the gravid females 
parasitic in the host's subcutaneous tissues, fins or the tissues of the buccal cavity, gill covers and gill arches: Philometra bagri, P. beninensis Obiekezie, 1986, P. cynoscionis, P. kohnae Moravec et Rohde, 1992, P. lomi Moravec et Rohde, 1992, P. macronesi (Shendge et Deshmukh, 1977), P. oreoleucisci Moravec et Ergens, 1970, P. overstreeti Moravec et de Buron, 2006, P. pinnicola (Yamaguti, 1935), P. plotosi Moravec et Nagasawa, 1989, P. poblana Caspeta-Mandujano, Granados Ramírez et Peralta-Rodríguez, 2009, P. rischta, P. sebastodis Yamaguti, 1941, P. strongylurae Moravec et Ali, 2005, P. sydneyi Rasheed, 1963 and P. tylosuri Moravec et Ali, 2005.

However, the majority of above-mentioned species are parasites of marine (9) or brackish-water (2) fishes and these distinctly differ morphologically from Philometra spiriformis (see Moravec 2006). Only five species were described from freshwater fishes: P. bagri from the subcutaneous tissue of the head and the inner surface of the gill covers of Bagrus bajad (Bagridae) in the Sudan and Egypt and Lake Turkana (this study); $P$. macronesi from the buccal cavity of Sperata seenghala (Sykes) (Bagridae) in India; P. oreoleucisci from the caudal fin of Oreoleuciscus spp. (Cyprinidae) in Central Asia; P. poblana from the skin at the base of pectoral fins of Cichlasoma istlanum (Jordan et Snyder) (Cichlidae) in Mexico; and $P$. rischta mainly from the inner surface of gill covers, but also the subcutaneous tissue of the head, fins or the buccal cavity of different species of cyprinids (Cyprinidae) in Palaearctic Eurasia.

Philometra bagri, P. oreoleucisci and P. rischta can be easily distinguished from $P$. spiriformis by the presence of four large cephalic lobes and conspicuously large caudal projections (Khalil 1965, Molnár 1966, Moravec and Ergens 1970, Moravec 2006, Sokolov and Kazakov 2007); cephalic lobes are absent and caudal projections are indistinct, hardly visible in $P$. spiriformis. Cephalic lobes are small in $P$. macronesi and absent in $P$. poblana, but caudal projections in both these species are rather large (Shendge and Deshmukh 1977, Caspeta-Mandujano et al. 2009); moreover, the gravid females of $P$. macronesi and $P$. poblana are only $10-14 \mathrm{~mm}$ and $7-10 \mathrm{~mm}$, respectively, long, whereas those of $P$. spiriformis are much longer (40-47 mm). Besides morphological differences, $P$. spiriformis also differs from these species, except for $P$. poblana, in the host type (Perciformes vs. Siluriformes or Cypriniformes) and, except for P. bagri, also in the geographical distribution (Ethiopian Region vs. Palaearctic or Oriental Regions). A marked characteristic feature of $P$. spiriformis is the spirally coiled body of both fixed and live gravid females, by which it can be differentiated from all congeners and nearly all philometrids. A spirally coiled body was previously described only in the gravid female of Spirophilometra eichleri Parukhin, 1971, a parasite of the spleen of the marine perciform fish Lethrinus
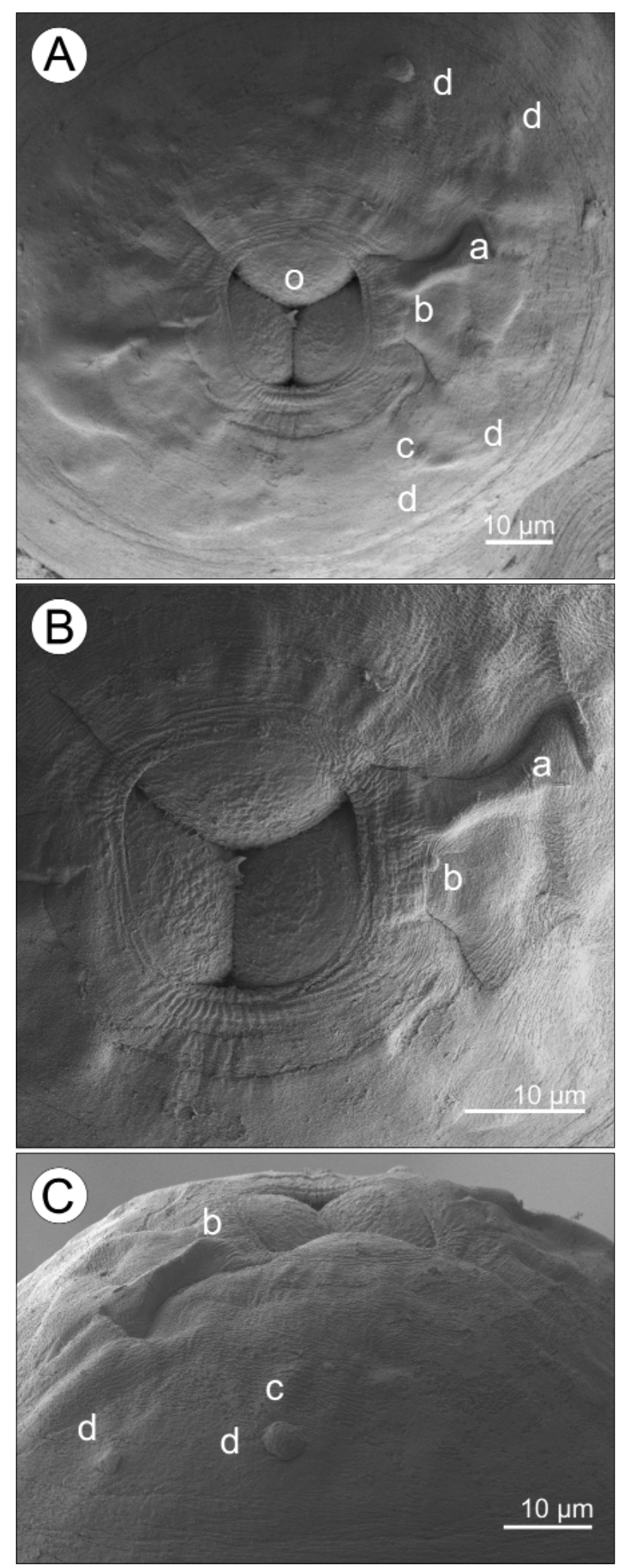

Fig. 6. Philometra spiriformis sp. n., scanning electron micrographs of gravid female. A - cephalic end, apical view; $\mathbf{B}$ - region of oral aperture, apical view; $\mathbf{C}$ - cephalic end, dorsal view. Abbreviations: $\mathrm{a}$ - amphid; $\mathrm{b}$ - lateral papilla of internal circle; $\mathrm{c}$ - submedian papilla of internal circle; $\mathrm{d}$ - submedian papilla of external circle; $\mathrm{o}-$ oral aperture. 
A

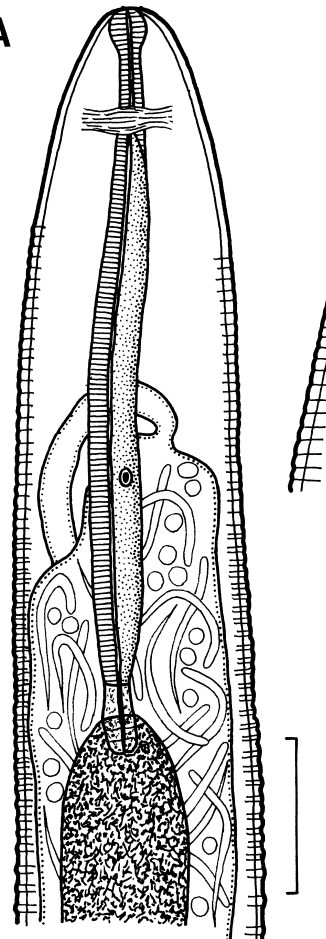

E

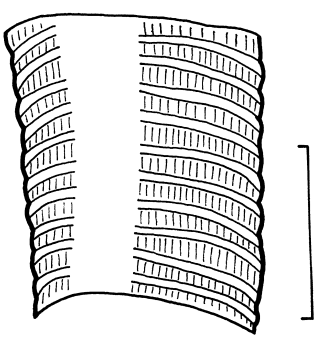

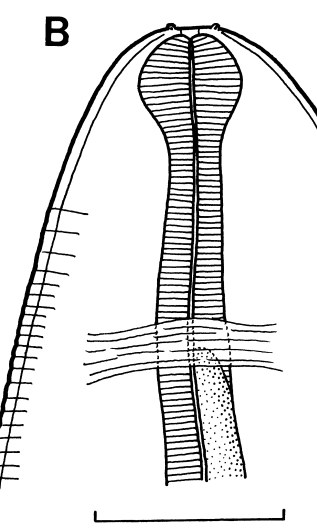

$\mathbf{F}$

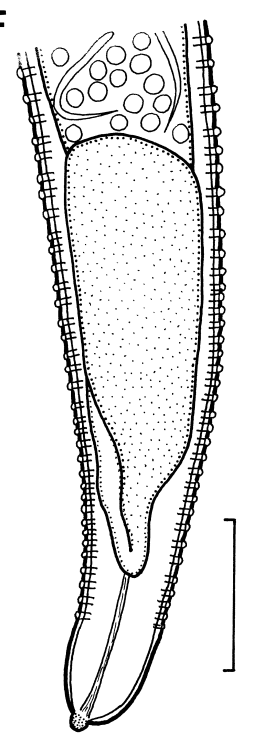

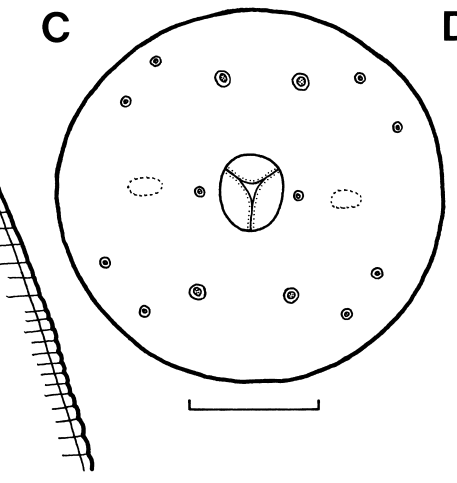

D
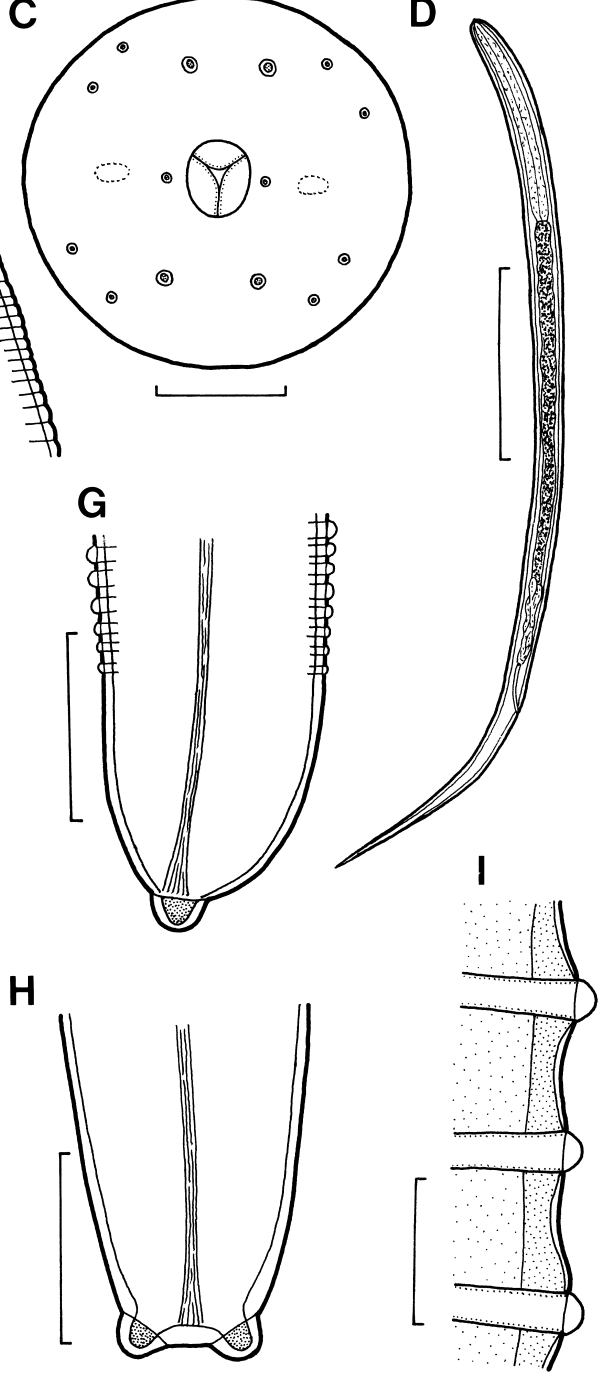

Fig. 7. Afrophilometra hydrocyoni (Fahmy, Mandour et El-Nafar, 1976) comb. n., gravid female. A - anterior part of body; B, C cephalic end, lateral and apical views; $\mathbf{D}$ - larva from uterus; $\mathbf{E}$ - body surface, lateral view; $\mathbf{F}$ - posterior part of body, lateral view; G, H - caudal end, lateral and ventral views; I - surface of body side. Scale bars: A, F = $200 \mu \mathrm{m} ; \mathrm{B}, \mathrm{D}, \mathrm{E}, \mathrm{H}=100 \mu \mathrm{m} ; \mathrm{C}=20 \mu \mathrm{m}$; $\mathrm{I}=30 \mu \mathrm{m}$.

nebulosus (Lethrinidae) in the Indian Ocean (Parukhin 1971).

\section{Afrophilometra gen. n.}

Diagnosis: Philometridae. Body of females elongated, cylindrical, with bluntly rounded ends. Dorsal and ventral body surface with numerous transverse semicircular bands of inflated cuticle separated by smooth lateral fields. Cephalic papillae small, arranged in two circles. Oesophagus short, cylindrical, expanded at anterior end; oesophageal gland well developed, mononucleate; small ventriculus present. Vulva and anus in gravid females atrophied. Ovaries in both body ends. Males unknown. Tissue parasites of African freshwater fishes.

Type- and the only species: A. hydrocyoni (Fahmy, Mandour et El-Nafar, 1976) comb. n.
Etymology: This generic name is composed of two parts, Afro (= African) and Philometra (= one of the related philometrid genera).

Afrophilometra hydrocyoni (Fahmy, Mandour et El-Nafar, 1976) comb. n.

Figs. 7, 8

Syn.: Philometroides hydrocyonae [sic] Fahmy, Mandour et El-Nafar, 1976.

Gravid female (1 specimen): Body of fixed specimen whitish (red when alive), $12.28 \mathrm{~mm}$ long, maximum width 422. Width of cephalic end 68, of posterior end 109. Maximum width/length ratio of body 1:29. Anterior part of body somewhat broader than posterior part. Almost whole body covered with numerous narrow transverse bands of inflated cuticle, interrupted by narrow smooth lateral fields; in lateral view, cuticular bands appearing as papil- 


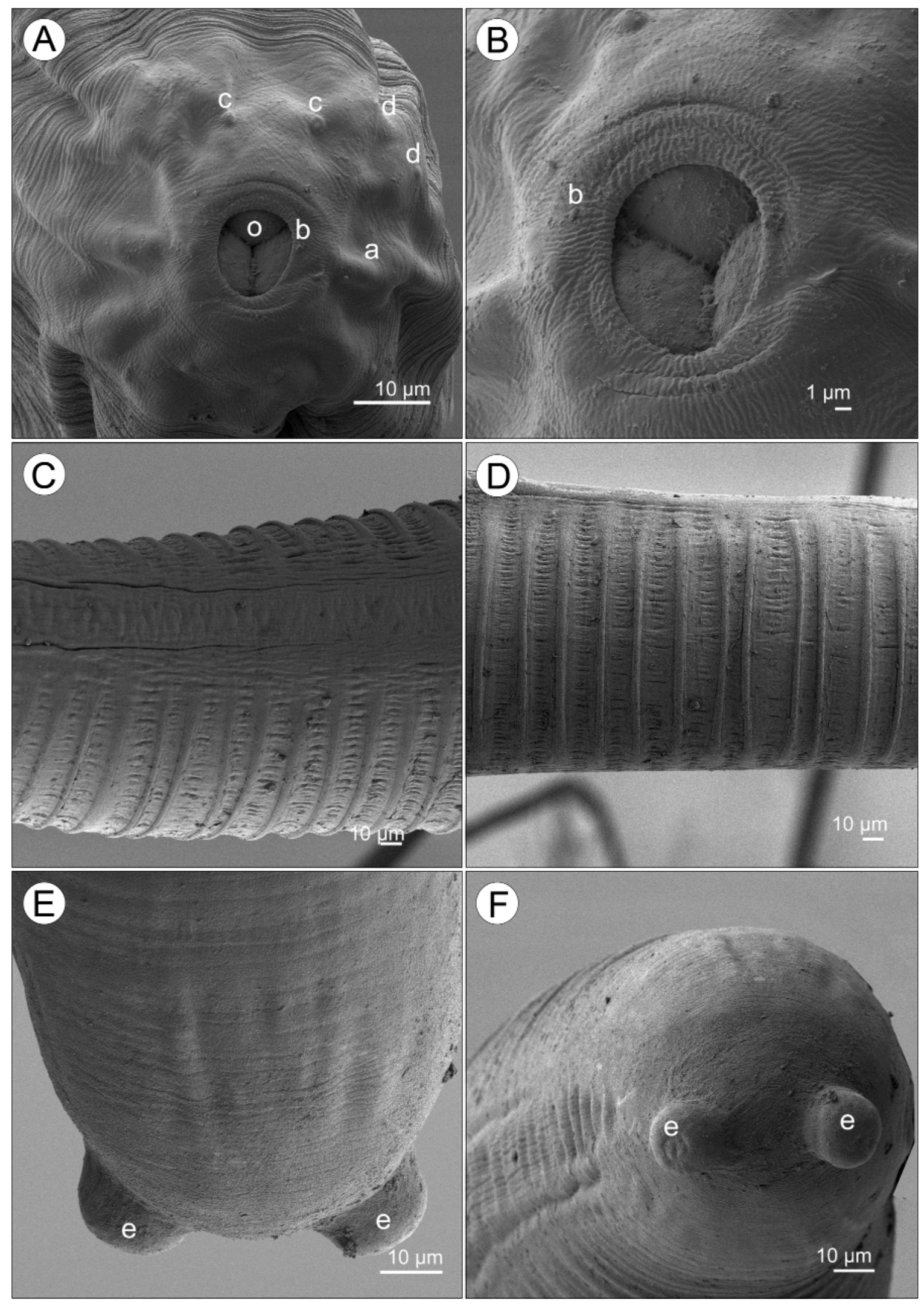

Fig. 8. Afrophilometra hydrocyoni (Fahmy, Mandour et El-Nafar, 1976) comb. n., scanning electron micrographs of gravid female. A - cephalic end, apical view; B - region of oral aperture, apical view; C, D - cuticular structures on body surface, lateral and dorsal views; E, F - caudal end, dorsoventral and apical views. Abbreviations: a - amphid; b - lateral papilla of internal circle; $\mathrm{c}$ - submedian papilla of internal circle; $d$ - submedian papilla of external circle; $\mathrm{e}$ - caudal projection; $\mathrm{o}$ - oral aperture. 

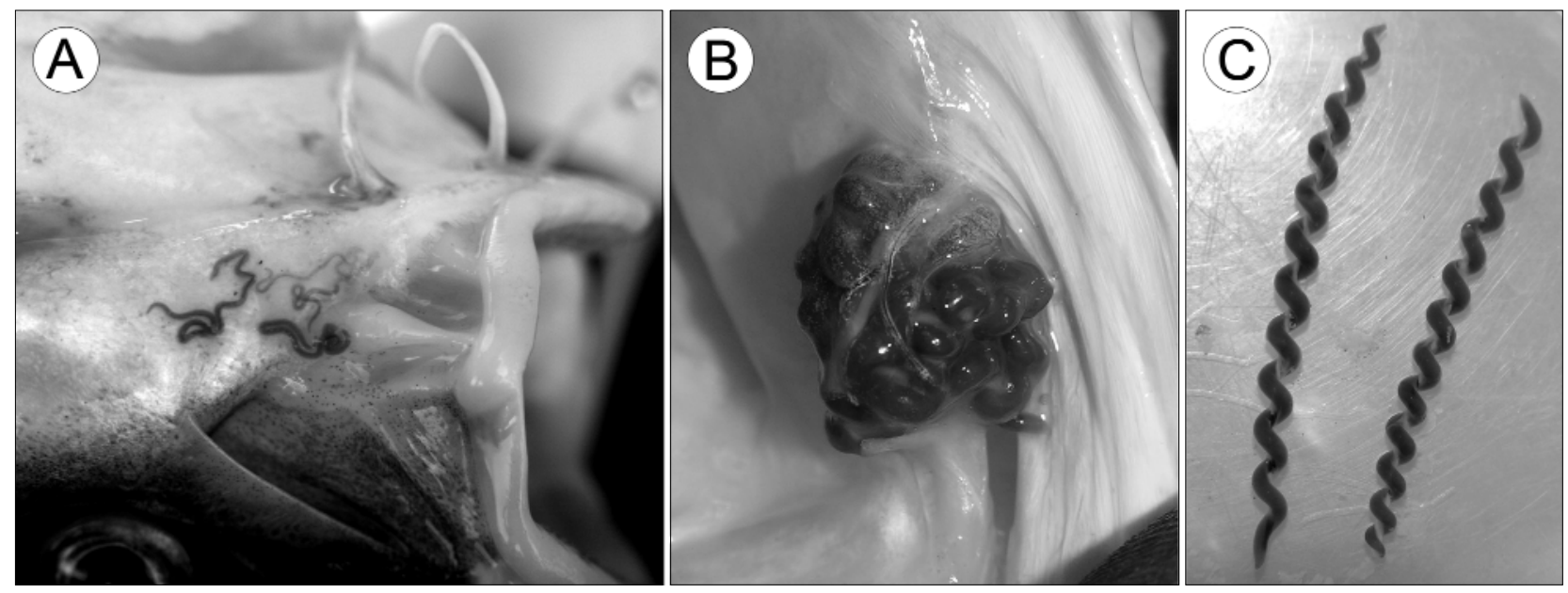

Fig. 9. Philometrids of Lake Turkana fishes in life and/or in-situ. Body colour of all live specimens was red. A - Philometra bagri insitu around mouth of Bagrus bajad: only specimens localized at non-pigmented (transparent) areas of skin are easily visible, whereas only barely discernible contours of the nematodes can be seen in other areas of the host's body (not shown) $(\times 0.8)$; $\mathbf{B}-$ transparent capsule on the inner surface of gill cover of Lates niloticus containing three specimens of Philometra spiriformis in-situ (type series) $(\times 4)$; $\mathbf{C}-$ two gravid females of $P$. spiriformis liberated from the capsule (the left specimen is holotype) $(\times 1.3)$.

lae on dorsal and ventral sides of body. These cuticular ornamentations starting anteriorly at level of about nerve ring and extending posteriorly to about mid-length of intestinal ligament; ornamentations gradually diminishing anteriorly at oesophageal region, being absent on both anterior and posterior body ends. Cephalic end rounded, with indistinct cephalic papillae. Oral aperture large, oval, surrounded by four submedian pairs of small, rounded papillae arranged in external circle and six (2 lateral and 4 submedian) rounded single papillae of internal circle; submedian papillae of inner circle slightly larger than other papillae. Bottom of mouth formed by flat surfaces of three oesophageal sectors. Anterior end of oesophagus forming distinct bulb 63 long and 60 wide. Greater posterior portion of oesophagus almost cylindrical, with well-developed dorsal oesophageal gland provided with large cell nucleus situated somewhat posterior to its middle; gland opening anteriorly at level of nerve ring; maximum width of this part of oesophagus including oesophageal gland 75. Entire oesophagus including anterior bulb 979 long, representing $8 \%$ of body length. Small ventriculus 48 long and 39 wide, opening into intestine through distinct valve. Nerve ring and cell nucleus of oesophageal gland 1190 and 693, respectively, from anterior extremity. Intestine light-coloured, narrow, ending blindly; its posterior part attached by ligament to body wall near posterior extremity. Posterior end of body rounded, bearing two large lateral papilla-like caudal projections 24 high.

\section{Male: Unknown}

H o s t: Hydrocynus forskahlii (Alestidae, Characiformes). Site of infection: Fins (tissue between fin rays).

L o c a lity: El-Molo Bay, Lake Turkana, Kenya. Collected in September 2007.
Prevalence and intensity: A single specimen of A. hydrocyoni found in 1 (SL: $270 \mathrm{~g}$ ) of $7 \mathrm{H}$. forskahlii examined in 2007 at El-Molo Bay. None of 24 H. forskahlii (12 from El-Molo Bay, 12 from Kalokol) examined from Lake Turkana in 2008 was infected.

Deposition of specimen: Voucher specimen in the Helminthological Collection of the Institute of Parasitology, Biology Centre of the Academy of Sciences of the Czech Republic, České Budějovice (Cat. No. N-912).

Comments: Because the males of many philometrid species and in some genera remain unknown, the present classification system of these nematodes is based essentially on the number, arrangement and character of female cephalic papillae and the structure of various cuticular ornamentations, which are considered the main taxonomic features (Rasheed 1963, Ivashkin et al. 1971, Chabaud 1975, Moravec 2004, 2006). Moravec (2006) recognized nine genera within the Philometridae, but an additional genus, Caranginema Moravec, Montoya-Mendoza et Salgado-Maldonado, 2008, has been established quite recently (Moravec et al. 2008d). The hitherto monotypic genus Afrophilometra differs from other philometrid genera with cuticular ornamentations mainly in that the body surface of its gravid female bears many transverse semicircular bands of inflated cuticle interrupted by narrow smooth lateral fields. In contrast, species of Spirophilometra have a cuticle densely covered with minute spines, whereas those of Buckleyella Rasheed, 1963, Caranginema, Nilonema Khalil, 1960, Paraphilometroides Moravec et Shaharom-Harrison, 1989 and Philometroides Yamaguti, 1935 possess other cuticular structures, namely individual bosses, cone-shaped or short transverse excrescences or rod-like structures (Moravec 2006, Moravec et al. 2008d). 
Even though the type specimens of Philometroides hydrocyonae [sic] were not available for study, there is no doubt that the nematodes from the fins of Hydrocynus forskahlii in Kenya belong to this species. The description provided by Fahmy et al. (1976) is inadequate, but the morphological and biometrical features of the present specimens agree, more or less, with data of those authors, the host species and the site of infection in fish are identical, and both localities in Egypt and Kenya belong to the Nilotic limnic system. Fahmy et al. (1976) reported the cuticle of this species to be provided with numerous bosses and, therefore, they assigned it to Philometroides. However, they studied these structures only under the light microscope, where the transverse bands of inflated cuticle appear as small bosses on the body sides (Fig. 7F,G,I). SEM examination of these cuticular structures shows clearly that they are very different from those in species of Philometroides or other genera possessing cuticular ornamentations and, therefore, a new genus Afrophilometra is proposed to accommodate this species, to which it is transferred as A. hydrocyoni (Fahmy, Mandour et ElNafar, 1976) comb. n. The number and arrangement of cephalic papillae in this species is described for the first time in this paper.
Afrophilometra hydrocyoni (as Philometroides hydrocyonae) was first described by Fahmy et al. (1976) from females found in fins and nearby muscles of Hydrocyon forskali (= Hydrocynus forskahlii) in the Nile River in Assiut, Egypt. From H. forskahlii and H. lineatus of the same locality it was also reported by El-Nafar et al. (1983) (see Khalil and Polling 1997). Fahmy et al. (1976) recorded this parasite in $50 \%$ of $H$. forskahlii of the Nile River in Assiut, with an intensity 4-8 nematodes per fish. The present finding of A. hydrocyoni in Kenya is the first record of this parasite outside Egypt, respectively the Nile basin.

Acknowledgements. Our thanks are due to the Laboratory of Electron Microscopy, Institute of Parasitology, Biology Centre of the ASCR, České Budějovice for technical assistance, Irena Husáková and Blanka Škoríková, Department of Helminthology at the same Institute, for help with illustrations. Special thanks go to Mikuláš Oros (Department of Helminthology, Institute of Parasitology, BC ASCR), Radim Blažek and Šárka Mašová (both Department of Parasitology, Masaryk University, Brno, Czech Republic) for their great help in the field and provision of Fig. 9C (by RB). This study was supported by the grant KJB600960813 from the Grant Agency of the Academy of Sciences of the Czech Republic, partly by the grant 524/06/0170 from the Grant Agency of the Czech Republic and research projects of the Institute of Parasitology, ASCR (Z60220518 and LC522).

\section{REFERENCES}

Boomker J. 1994: Parasites of South African freshwater fish. VI. Nematode parasites of some fish species in the Kruger National Park. Onderstepoort J. Vet. Res. 61: 35-43.

Caspeta-Mandujano J.M., Granados Ramírez J.G, PeraltaRodríguez J.L. 2009: A new philometrid species (Nematoda) from the freshwater fish Cichlasoma istlanum (Jordan and Snyder, 1899) (Cichlidae) in Mexico. J. Parasitol. - in press.

Chabaud A.G. 1975: Keys to genera of the order Spirurida. Part 1. Camallanoidea, Dracunculoidea, Gnathostomatoidea, Physalopteroidea, Rictularoidea and Thelazioidea. In: R.C. Anderson, A.G. Chabaud and S. Willmott (Eds.), CIH Keys to the Nematode Parasites of Vertebrates. No. 3. Commonwealth Agricultural Bureaux, Farnham Royal, Bucks (UK), 27 pp.

El-Nafar M.K., Saoud M.F., Hassan I.M. 1983: A general survey of the helminth parasites of some fishes of Lake Nasser at Aswan, A. R. Egypt. Assiut Vet. Med. J. 11: 141-183.

Fahmy M.A.M., Mandour A.M., El-Nafar M.K. 1976: On some nematode parasites from the freshwater fishes in Assiut Province, Egypt. Vet. Med. J. (Egypt) 24: 263-276.

Froese R., Pauly D. (Eds.) 2009: FishBase. World Wide Web electronic publication, www.fishbase.org, 2/2009.

Ivashrin V.M., Sobolev A.A., Khromova L.A. 1971: [Camallanata of animals and man and the diseases caused by them. Osnovy nematodologii 22.] Nauka, Moscow, 388 pp. (In Russian.)

KHALIL L.F. 1960: On a new nematode, Nilonema gymnarchi gen. et sp. nov., (Dracunculidae), from a freshwater fish in the Sudan. J. Helminthol. 34: 55-58.

KHALIL L.F. 1965: On a new philometrid nematode, Thwaitia bagri sp. nov., from a freshwater fish in the Sudan. J. Helminthol. 39: 309-312.
KHaLIL L.F. 1969: Studies on the helminth parasites of freshwater fishes of the Sudan. J. Zool., London, 58: 143-170.

KHaliL L.F. 1974: Some nematodes from the freshwater fishes of Rhodesia with the description of a new species Cithariniella petterae n. sp. Ann. Parasitol. Hum. Comp. 48: 811-818.

Khalil L.F., Polling L. 1997: Check List of the Helminth Parasites of African Freshwater Fishes. Second edition. University of the North, Pietersburg, $185 \mathrm{pp}$.

MolnÁR K. 1966: On some little-known and new species of the genera Philometra and Skrjabillanus from fishes in Hungary. Acta Vet. Acad. Sci. Hung. 16: 143-158.

Moravec F. 1994: Parasitic Nematodes of Freshwater Fishes of Europe. Academia and Kluwer Academic Publishers, Prague and Dordrecht, Boston, London, $473 \mathrm{pp}$.

Moravec F. 2004: Some aspects of the taxonomy and biology of dracunculoid nematodes parasitic in fishes: a review. Folia Parasitol. 51: 1-13.

Moravec F. 2006: Dracunculoid and Anguillicoloid Nematodes Parasitic in Vertebrates. Academia, Prague, 634 pp.

Moravec F. 2008: Systematic status of Philometra jordanoi (López-Neyra, 1951) and some other congeneric species previously identified as Philometra lateolabracis (Yamaguti, 1935) (Nematoda: Philometridae). Folia Parasitol. 55: 159-160.

Moravec F., Ali A.H. 2005: Two new species of Philometra (Nematoda: Philometridae) from needlefishes (Belonidae) in Iraq, with a key to Philometra spp. parasitic in the host's subcutaneous tissue, fins and musculature. Folia Parasitol. 52: 267-273.

Moravec F., Crosby M.D., de Buron I., González-Solís D., Roumillat W.A. 2008a: Three new species of philometrids (Nematoda: Philometridae) from centrarchid fishes in the USA. J. Parasitol. 94: 1103-1113. 
Moravec F., De Buron I. 2006: Two new species of philometrid nematodes (Nematoda: Philometridae) from the southern flounder Paralichthys lethostigma in the estuaries of South Carolina, USA. Folia Parasitol. 53: 139-146.

Moravec F., de Buron I., Baker T.G. González-Solís D. 2008b: Some gonad-infecting species of Philometra (Nematoda, Philometridae) from offshore fishes of South Carolina and Georgia, USA, including Philometra charlestonensis sp. nov. from the scamp Mycteroperca phenax. Acta Parasitol. 53: 382-391.

Moravec F., de Buron I., Roumillat W.A. 2006: Two new species of Philometra (Nematoda: Philometridae) parasitic in the perciform fish Cynoscion nebulosus (Sciaenidae) in the estuaries of South Carolina, USA. Folia Parasitol. 53: 63-70.

Moravec F., Ergens R. 1970: Nematodes from fishes and cyclostomes of Mongolia. Folia Parasitol. 17: 217-232.

Moravec F., Gaglio G., Panebianco A., Giannetto S. 2008c: Two species of Philometra (Nematoda: Philometridae) from sparid fishes (porgies) off Sicily, Italy, including Philometra obladae sp. n. from the body cavity of Oblada melanura (Sparidae). Parasitol. Res. 104: 55-61.

Moravec F., Justine J.-L. 2008: Some philometrid nematodes (Philometridae), including four new species of Philometra, from marine fishes off New Caledonia. Acta Parasitol. 53: 369-381.

Moravec F., Lorber J., Konečný R. 2007a: Two new species of parasitic nematodes from the dogtooth tuna Gymnosarda unicolor (Pisces) off the Maldive Islands. J. Parasitol. 93: 171-178.

Moravec F., Montoya-Mendoza J., Salgado-Maldonado G. 2008d: A new genus and species of philometrid (Nematoda) from the subcutaneous tissue of the crevalle jack, Caranx hippos (Osteichthyes), from the southern Gulf of Mexico. J. Parasitol. 94: 1346-1350.

Moravec F., Salgado-Maldonado G. 2007: A new species of Philometra (Nematoda, Philometridae) from the gonads of the

Received 16 December 2008 rock hind Epinephelus adscensionis (Osteichthyes) from the southern Gulf of Mexico. Acta Parasitol. 52: 376-381.

Moravec F., Santana-Piñeros A., González-Solís D., TorresHuerta A.M. 2007b: A new species of Spirophilometra (Nematoda: Philometridae) from the yellowfin snook Centropomus robalito (Osteichthyes) in southern Mexico. Folia Parasitol. 54: 215-219.

Moravec F., Van As J.G. 2001: Philometroides africanus sp. n. (Nematoda: Philometridae), a new tissue parasite of the African pike Hepsetus odoe (Pisces) in Botswana. Folia Parasitol. 48: 127-131.

PARUKhin A.M. 1971: Spirophilometra eichleri n. g. n. sp., ein neuer Fisch-Nematode aus dem Indik. Angew. Parasitol. 12: 220-224.

Quiazon K.M.A., Yoshinaga T., Ogawa K. 2008a: Taxonomical study into two new species of Philometra (Nematoda: Philometridae) previously identified as Philometra lateolabracis (Yamaguti, 1935). Folia Parasitol. 55: 29-41.

Quiazon K.M.A., Yoshinaga T., Ogawa K. 2008b: Philometra sawara sp. n. and a re-description of Philometra sciaenae Yamaguti, 1941 and Philometra nemipteri Luo, 2001 (Nematoda: Philometridae): a morphological and molecular approach. Folia Parasitol. 55: 277-290.

Rasheed S. 1963: A revision of the genus Philometra Costa, 1845. J. Helminthol. 37: 89-130.

Shendge S.R., Deshmukh P.G. 1977: Thwaitia macronesi n. sp. (Nematoda: Philometridae) from the fish, Macrones seenghala. Riv. Parassitol. 38: 157-160.

Sokolov S.G., Kazakov B.E. 2007: [Redescription of the male of Philometra rischta Skrjabin, 1923 (Nematoda: Dracunculoidea: Philometridae) and notes on morphology of the female of this species]. Zoologiya Bespozvonochnykh 4: 151-160. (In Russian with English abstract.) 